\title{
Protective effects of Sanguisorba minor and Ferulago angulata total extracts against beta-amyloid induced cytotoxicity and oxidative stress in cultured cerebellar granule neurons
}

\author{
Sholeh Akbari $^{\mathbb{D}}$, Maliheh Soodi ${ }^{*{ }^{\mathbb{D}}}$, Homa Hajimehdipoor ${ }^{2}$, Nasim Ataei ${ }^{1}$ \\ ${ }^{1}$ Department of Toxicology, Faculty of Medical Sciences, Tarbiat Modares University, Tehran, Iran \\ ${ }^{2}$ Traditional Medicine and Materia Medica Research Center and Department of Traditional Pharmacy, School of Traditional Medicine, Shahid Beheshti \\ University of Medical Sciences, Tehran, Iran
}

\section{A R T I C L E I N F O}

Article Type:

Original Article

\section{Article History:}

Received: November 192018

Accepted: February 232019

\section{Keywords:}

Sanguisorba minor

Ferulago angulata

Alzheimer's disease

Oxidative stress

Neuroprotection

\begin{abstract}
A B S T R A C T
Introduction: Alzheimer's disease (AD) is an age-dependent neurodegenerative disorder and major cause of mortality in the elderly. AD has a complex pathophysiology and needs new multi-targeted compounds to halt the disease progression through several mechanisms. Medicinal plants contain various compounds with heterogeneous pharmacological effects, therefore are a good source. The aim of this study was to evaluate the protective effect of total extracts of Sanguisorba minor and Ferulago angulata on beta-amyloid (A $\beta$ )-induced toxicity in primary neural cell culture.

Methods: Cerebellar granule neurons (CGNs) were cultured according to standard protocols. The cultured neurons were incubated with $A \beta$ alone or in combination with different concentrations of extracts for 24 hours. Cell viability was measured by methylthiazolyldiphenyltetrazolium (MTT) assay. In addition acetylcholinesterase (AChE) activity and oxidative stress markers were measured after incubation. Also, the effects of different concentrations of the extracts on AChE activity of the cultured neurons were investigated. For measuring the acute toxicity of the extract, LD50 was estimated by limit test.

Results: Both extracts could protect CGNs against A $\beta$-induced cell death. A $\beta$-induced oxidative stress and increase of AChE activity were ameliorated by both extracts. $S$. minor extract dosedependently reduced AChE activity in cultured CGNs. LD50 of both extracts was estimated above $2000 \mathrm{mg} / \mathrm{kg}$ and considered as safe.

Conclusion: Both studied extracts protected CGNs against A $\beta$-induced toxicity by ameliorating oxidative stress mechanism. According to these results, these extracts are recommended for further investigation in $\mathrm{AD}$ treatment.
\end{abstract}

\section{Implication for health policy/practice/research/medical education:}

Results of our study indicated that Sanguisorba minor and Ferulago angulata total extracts protect against beta-amyloid(A $\beta)$ induced neurotoxicity through attenuating the oxidative stress. Because $A \beta$ has a crucial role in pathogenesis and progression of Alzheimer's disease then it is suggested that these two plant extracts contain metabolites with potential anti-Alzheimer effects. Hence, they are recommended for further investigation to find out a new treatment for AD.

Please cite this paper as: Akbari S, Soodi M, Hajimehdipoor H, Ataei N. Protective effects of Sanguisorba minor and Ferulago angulata total extracts against beta-amyloid induced cytotoxicity and oxidative stress in cultured cerebellar granule neurons. J Herbmed Pharmacol. 2019;8(3):248-255. doi: 10.15171/jhp.2019.36.

\section{Introduction}

Alzheimer's disease (AD) is an age-dependent neurodegenerative disease which was first described by Alois Alzheimer in 1907. It is an irreversible and progressive neurodegenerative disease characterized by a group of cognitive and non-cognitive dysfunctions such as memory loss, language difficulties, psychiatric symptoms and behavioral disturbances $(1,2)$. $\mathrm{AD}$ is a complex disorder and several hypotheses have been proposed for $\mathrm{AD}$ pathogenesis but the most important hypotheses suggested to the pathophysiology of $\mathrm{AD}$ include Cholinergic hypothesis and Amyloid cascade hypothesis (3). Loss of cholinergic neurons and diminished level of acetylcholine neurotransmitter were observed in memory loss in $\mathrm{AD}$ patients, and restoration of brain cholinergic function by acetylcholinesterase inhibitors (AChEIs), 
symptomatically improves memory impairment in $\mathrm{AD}$ patients. According to this hypothesis, AChEI medications are currently available therapy for $\mathrm{AD}$ patients but these drugs are useful for symptomatic treatment and do not cure the disease (4).

Two major pathological findings in the $\mathrm{AD}$ patient brains are extracellular senile plaques and intracellular neurofibrillary tangles. The major components of senile plaques are amyloid beta $(A \beta)$ peptides. The $A \beta$ peptides are 39-43 amino acid peptides produced by proteolytically cleavage of $A \beta$ protein precursor protein (APP) by $\gamma$-secretase and $\beta$-secretase enzymes (5). The "Amyloid cascade hypothesis" suggested that abnormal accumulation of $A \beta$ peptide initiates a cascade resulted in neuronal dysfunction and death (6). Various studies have indicated that $A \beta$ peptide has neurotoxic properties both in vitro and in vivo $(7,8)$. Several mechanisms proposed for the neurotoxicity of $A \beta$ peptide include oxidative stress, mitochondrial dysfunction, interaction with ion channel, alterations in membrane permeability, alterations in glutamate receptors and excitotoxicity and induction of inflammatory responses (9). The A $\beta$ peptide plays a crucial role in the pathogenesis of $\mathrm{AD}$, then modulation of $A \beta$ toxicity is a major focus of several studies as an important therapeutic approach to control the onset and progressive of $\mathrm{AD}(10,11)$.

Because of complex pathophysiology of $\mathrm{AD}$, single targeted drugs have limited effects and new researches are focusing on multi-targeted drugs (12-14). Medicinal plants contain a variety of bioactive compounds with potent biological activities. Then, the medicinal plants appear to be a promising source for identification of bioactive compounds which can be used in the treatment of $\mathrm{AD}(15,16)$. Some herbal extracts have been effective in treating $\mathrm{AD}$ in animal models and even in clinical studies $(17,18)$.

The plants of Rosaceae family are used in traditional and folklore medicine of many countries. Sanguisorba minor is a plant belonging to the genus Sanguisorba, a member of Rosaceae family. The plants of Sanguisorba spp. are rich in bioactive compounds and more than 120 compounds have been isolated from this genus including terpenoids, phenols and flavonoids. Sanguisorba plants have high amounts of polyphenols and have strong antioxidant activity. These plants also show neuroprotective activity. Studies have indicated that Sanguisorba spp. extracts inhibit AChE activity and the glycogen synthase kinase $3 \beta$ (GSK3) (19,20). Both of these enzymes have important roles in AD (21). Among Sanguisorba species, S. minor has been shown to have the most inhibitory effect on the AChE enzyme (22).

Ferulago angulata is a medicinal plant from Apiaceae family, which is mostly indigenous to western Iran, Turkey and Iraq. Eight species exist in Iran of which three are native. The genus Ferulago is a source of biologically active compounds such as coumarins, sesquiterpenes, monoterpenes, phenylpropanoids and flavonoids. The genus Ferulago has different biological activities such as anti-inflammatory, antioxidant and anti-cancer and antidiabetic effects (23). In addition, several neuroprotective activities were reported for Ferulago angulata extract $(24,25)$. In the present study, anti-Alzheimer effects of $S$. minor and F. angulata were investigated in a primary neuron culture.

\section{Materials and Methods}

Dulbecco's modified Eagle's Medium (DMEM), fetal bovine serum (FBS), penicillin-streptomycin (10000 U/ $\mathrm{mL}$ ) and trypsin (0.25\%) were taken from GIBCO (USA). Poly-D-lysine (PDL) was purchased from Santa Cruz Biotechnology Inc. (USA). Beta amyloid peptide (AB 2535) was purchased from Enzo Life Sciences (Farmingdale, USA). All other materials were purchased from Sigma (USA).

\section{Plant material}

Ferulago angulata and S. minor were collected from Kohgiluyeh Va Boyer Ahmad and Hamedan provinces of Iran, respectively. They were identified by the botanists of the Traditional Medicine and Materia Medica Research Center (TMRC), Shahid Beheshti University of Medical Sciences and their voucher specimens were deposited at TMRC Herbarium for future reference (No. 2800 TMRC and No. 3545 TMRC, for F. angulata and S. minor, respectively).

\section{Plant extraction}

The total extract was obtained by maceration method. The aerial parts of collected plants were dried in shade and ground. $100 \mathrm{~mL}$ of methanol: water (80:20) was added to $10 \mathrm{~g}$ of the plant powder. Every 24 hours, the mixture was filtered and fresh solvent was added for 3 days. All extracts were combined and dried by rotary evaporator and freeze dryer.

\section{Measurement of total phenolic compounds}

The total phenolics contents of the extracts were determined spectrophotometrically according to the Folin-Ciocalteu method using gallic acid as the standard. The methanolic solution of the extracts or gallic acid $(400 \mu \mathrm{L})$ were mixed with Folin-Ciocalteu's reagent (3 $\mathrm{mL}$ ) and incubated at $22^{\circ} \mathrm{C}$ for 5 minutes. Then, $3 \mathrm{~mL}$ sodium carbonate $(7 \%)$ was added and the reaction mixture was further incubated at $22^{\circ} \mathrm{C}$ for 90 minutes. The absorbance was then, determined at $725 \mathrm{~nm}$. The total phenolics content was expressed as gallic acid equivalent in milligram per $100 \mathrm{~g}$ dried extract (17).

Primary culture of cerebellar granule neurons Cerebellar granule neurons (CGNs) were cultured as 
described previously (26). Cerebella were dissected from the brain of 6-7 day-old mice $(\mathrm{BALB} / \mathrm{c})$. A single cell suspension was obtained from dissected Cerebella by digestion with trypsin and triturating. Then, cell suspension was seeded on PDL-coated cell culture plates. Culture medium was DMEM containing 10\% FBS, 25 $\mathrm{mM} \mathrm{KCl}, 4.5 \mathrm{~g} / \mathrm{L}$ glucose, insulin $(100 \mathrm{mU} / \mathrm{L})$, penicillin and streptomycin $1 \%(\mathrm{v} / \mathrm{v})$. The cultured cell plates were maintained at $37^{\circ} \mathrm{C}$ in a humidified atmosphere with $5 \%$ CO2. 48 hours after cell plating, the half of culture medium was replaced by medium containing cytosine $\beta$-D-arabinofuranoside (Ara-C) at a final concentration of $20 \mu \mathrm{M}$ to inhibit the growth of non-neuronal cells. After that, the medium was not changed during culture. After 7 days of in vitro (DIV7) in this condition, MAP2 protein immune-staining indicated that more than $95 \%$ of cells in culture were neurons. Therefore, the cultured neurons were matured on DIV7 and all experiments were done on matured neurons.

\section{Treatment}

CGNs were plated onto PDL coated 96-well plate (1 $\times 10^{5}$ cell/well) and on DIV 7 , incubated with $10 \mu \mathrm{M}$ aggregated $\mathrm{A} \beta$ alone or in combination with different concentrations of extracts for 24 hours, then the cell viability was measured by MTT assay. A $\beta$ 25-35 was reconstituted in sterile water at a concentration of $1 \mathrm{mM}$. Aliquots were incubated at $37^{\circ} \mathrm{C}$ for 72 hours to form aggregated amyloid. The stock solutions of the plant extracts were prepared by dissolving in DMSO. The diluted plant extracts were daily prepared by dilution of the stock solution by culture medium. The concentration of DMSO in the culture medium was $0.5 \%$ or less.

\section{Cell viability test}

Neuronal survival was quantified by methyl tetrazolium salt (MTT) reduction assay. This assay is based on the ability of mitochondria dehydrogenase enzyme from viable cells to cleave the tetrazolium rings of the pale yellow MTT and form dark blue formazan crystals. After incubation time, the culture medium was replaced with MTT $(0.5 \mathrm{mg} / \mathrm{mL})$ containing medium and incubated for 4 hours, then the medium was removed and $100 \mathrm{~mL}$ DMSO was added to each well to dissolve formazan crystals. The absorbance was measured by ELISA reader (BIOTEK) at a wavelength of 570 against $630 \mathrm{~nm}$ as the reference wavelength. Data are expressed as the percentage of control (27).

\section{Measurement of reactive oxygen species}

Reactive oxygen species (ROS) generation in cells was evaluated by a fluorescent probe 2,7-dichlorodihydrofluorescein diacetate (DCFHDA). DCFH-DA crosses cell membranes and is hydrolyzed enzymatically to nonfluorescent dichlorodihydrofluorescein (DCFH). It is often used as an indicator of ROS. ROS in the cells cause oxidation of DCFH and convert it to highly fluorescent dichlorofluorescein (DCF) compound. Cells were plated onto PDL coated 96-well plate $\left(1 \times 10^{5}\right.$ cell/well $)$, on DIV7, incubated with $10 \mu \mathrm{g} / \mathrm{mL} \mathrm{A} \beta$ alone or with extracts of $F$. angulata $(50 \mu \mathrm{g} / \mathrm{mL})$ and $S$. minor $(75 \mu \mathrm{g} / \mathrm{mL})$ for 24 hours. After the incubation time, the medium was replaced by fresh medium containing $10 \mu \mathrm{M}$ DCFH-DA and incubated at $37^{\circ} \mathrm{C}$ for 15 minutes. Then, the medium was removed and the cells were rinsed twice with $\mathrm{Ca}^{2+}$-free PBS. The fluorescence was monitored by Fluorescence microplate reader (BIOTEK) at the excitation wavelength of $488 \mathrm{~nm}$ and the emission wavelength of $525 \mathrm{~nm}$ (28).

\section{Measurement of glutathione peroxidase}

Glutathione peroxidase (GPx) activity in CGNs was measured by the colorimetric kit (BioVision). CGNs were plated onto PDL coated 6 -well plate $\left(3 \times 10^{6}\right.$ cell/well $)$, on DIV 7, incubated with $10 \mu \mathrm{M} \mathrm{A} \beta$ alone or with extracts of F. angulata $(50 \mu \mathrm{g} / \mathrm{mL})$ and $S$. minor $(75 \mu \mathrm{g} / \mathrm{mL})$ for 24 hours. After the incubation, the cells were washed with PBS and removed from culture plate, then, homogenized in PBS with sonication. The homogenate was centrifuged at $1000 \mathrm{~g}$ for 10 minutes and the supernatant was used for enzyme activity and protein assay. GPx activity was measured according to kit instruction. Data were expressed as $\mathrm{mU} / \mathrm{mg}$ protein. The amount of protein was obtained by Bradford method.

\section{Measurement of acetylcholinesterase activity}

CGNs were plated onto PDL coated 6-well plate $\left(3 \times 10^{6}\right.$ cell/well), on DIV 7, incubated with $10 \mu \mathrm{M} A \beta$ alone or with extracts of $F$. angulata $(50 \mu \mathrm{g} / \mathrm{mL})$ and $S$. minor $(75 \mu \mathrm{g} / \mathrm{mL})$ for 24 hours. Also, the effect of different concentrations of extracts on AchE activity of CGNs was measured. For this end, the cultured CGNs were incubated with different concentrations of each extract on DIV 7 and AChE activity was measured after 24 hours. After the incubation, the cells were washed with PBS and removed, then, homogenized in PBS with sonication. The homogenate was centrifuged at $1000 \mathrm{~g}$ for 10 minutes and the supernatant was used for enzyme activity and protein assay. AChE activity was determined using Ellman's method (29). Briefly, Ellman reagent $(100 \mu \mathrm{L})$ containing phosphate buffer $(\mathrm{pH}=8,0.1 \mathrm{M})$, ATCh $75 \mathrm{mM}$ as a substrate, and dithionitrobenzoic acid (DTNB) $10 \mathrm{mM}$ in a ratio of 150:2:5, was transferred to the 96-well plate and then $50 \mu \mathrm{L}$ cell lysate was added to the reaction mixture as an enzyme source. The absorbance was measured at 405 $\mathrm{nm}$ for 15 minutes. A blank containing all components except cell lysate was run in parallel with a sample to eliminate the spontaneous and non-enzymatic breakdown of DTNB, and then the reactions rate was calculated. The amount of protein was obtained by Bradford method.

\section{$\mathrm{LD}_{50}$ estimation}

The $\mathrm{LD}_{50}$ was estimated by the limit test method according 
to the OECD protocol. According to this protocol, one female animal is orally administered a single dose of $2000 \mathrm{mg} / \mathrm{kg}$ by gavage and the animal is monitored for 48 hours. If an animal dies the main test conducts, if not, four additional animals are gavaged the same dose. If three or more animals survive, the $\mathrm{LD}_{50}$ is greater than $2000 \mathrm{mg}$ / $\mathrm{kg}$. In the present study, because the first mice survived, four additional mice were gavaged the same dose of 2000 $\mathrm{mg} / \mathrm{kg}$, sequentially. Because all mice were survived, $\mathrm{LD}_{50}$ was considered to be more than $2000 \mathrm{mg} / \mathrm{kg}$ for both extracts. All animals were evaluated for 14 days in terms of mortality, apparent health and weight (30).

\section{Statistical analysis}

Results are expressed as mean \pm standard error (SE). Statistically significant differences between groups were evaluated by one-way ANOVA followed by Tukey post hoc test. GraphPad PRISM 6 software was used for statistical analyses. $P<0.05$ was considered to indicate a statistically significant difference.

\section{Results}

Amount of total phenolic compounds in the extracts The total phenolic contents of the extracts were $11.06 \pm 0.55$ and $2.11 \pm 0.08$ for S. minor and F. angulate extracts respectively. The data were obtained according to calibration curves of gallic acid ( $y=2.6 x-0.038, r 2=0.99)$. The amount of phenolic compounds in the extracts are shown as equivalent of the gallic acid (mg) in $100 \mathrm{~g}$ dry extract.

Protective effects of Sanguisorba minor and Ferulago angulata extracts on $\mathrm{A} \beta$ - induced cytotoxicity Effects of $S$. minor and $F$. angulata extracts on $\mathrm{A} \beta$ induced cytotoxicity in cultured CGNs are shown in Figure 1. Treatment of CGNs with $\mathrm{A} \beta(10 \mu \mathrm{M})$ for 24 hours significantly reduced the cell viability $(P<0.001)$. Co-treatment of the CGNs with different concentrations of $S$. minor extract and $A \beta$ significantly reduced the $A \beta$ induced cytotoxicity. The maximum protective effect was observed at $75 \mu \mathrm{g} / \mathrm{mL}$ concentration, and above this concentration had less protective effect (Figure 1A). Also, F. angulata extract at concentration range of 5-200 $\mu \mathrm{g} /$ $\mathrm{mL}$ could attenuate $\mathrm{A} \beta$-induced cytotoxicity and the concentration of $50 \mu \mathrm{g} / \mathrm{mL}$ the most protective effect was observed (Figure 1B). In Figure 1C the protective effects of the extracts are compared with protective effects of donepezil, BHT and memantine against the $\mathrm{A} \beta$-induced cytotoxicity in CGNs. According to the results, the extracts had more protective effect than donepezil, BHT and memantine.

Effect of Sanguisorba minor and Ferulago angulata on ROS production

ROS production was measured by fluorimetric method. The result indicated that incubation of CGNs with $\mathrm{A} \beta$ (10

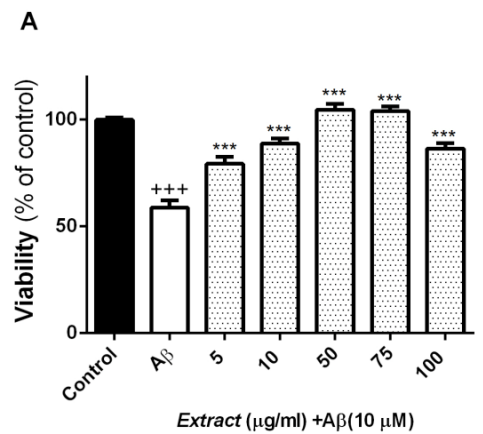

B

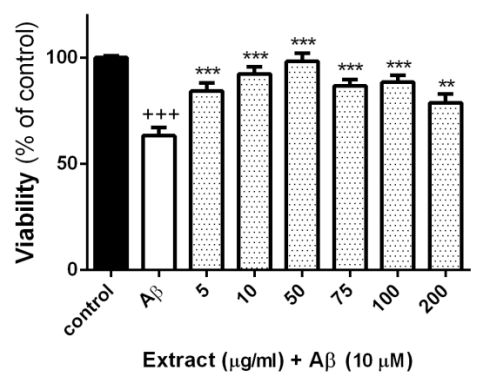

C

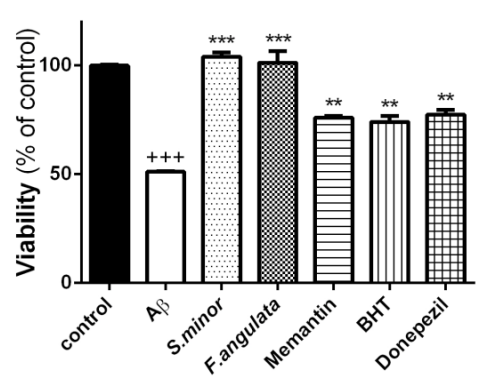

Figure 1. Effects of the Sanguisorba minor and Ferulago angulata extracts on $A \beta$-induced cytotoxicity in cerebellar granule neurons (CGNs). (A) Sanguisorba minor, (B) Ferulago angulata, (C) comparison of protective effects of extracts with memantine, donepezil and $\mathrm{BHT} .{ }^{+++} P<0.001$ vs. control, ${ }^{* *} P<0.01$, and ${ }^{* * *} P<0.001$ vs. $A \beta-$ treated group.

$\mu \mathrm{M})$ significantly increased fluorescent intensity which indicates significant ROS production. Both S. minor $(75 \mu \mathrm{g} / \mathrm{mL})$ and $F$. angulata $(50 \mu \mathrm{g} / \mathrm{mL})$ significantly ameliorated $\mathrm{A} \beta$-induced ROS production in CGNs. Also, S. minor $(75 \mu \mathrm{g} / \mathrm{mL})$ and F. angulata $(50 \mu \mathrm{g} / \mathrm{mL})$ alone did not affect ROS level in CGNs (Figure 2).

Effect of Sanguisorba minor and Ferulago angulata on GPx activity

GPx is the most important antioxidant enzyme in the cells. Treatment of CGNs with $\mathrm{A} \beta(10 \mu \mathrm{M})$ significantly decreased GPx activity as compared with the control group. When cells were co-treated with $\mathrm{A} \beta(10 \mu \mathrm{M})$ and S. minor extract $(75 \mu \mathrm{g} / \mathrm{mL})$ or with $\mathrm{A} \beta(10 \mu \mathrm{M})$ and $F$. angulata extract $(50 \mu \mathrm{g} / \mathrm{mL})$ for 24 hours, GPx activity significantly increased as compared with $\mathrm{A} \beta$ group (Figure 3). 


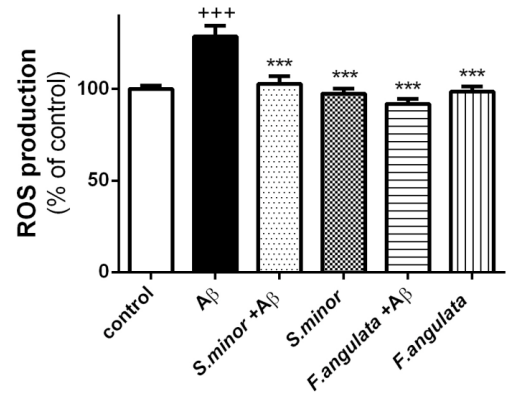

Figure 2. Comparison of ROS production in cerebellar granule neurons after treatment with $A \beta$ alone or in combination with extracts. ${ }^{+++} P<0.001$ vs. control, ${ }^{* * *} P<0.001$ vs. A $\beta$-treated group.

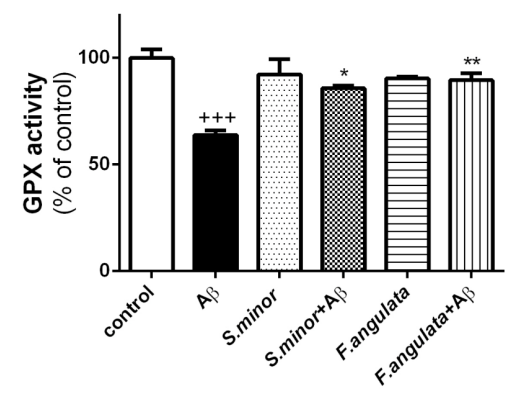

Figure 3. Comparison of glutathion peroxidase (GPx) activity in cerebellar granule neurons after treatment with $A \beta$ alone or in combination with extracts. ${ }^{++} P<0.001$ vs. control, ${ }^{*} P<0.05$ and ${ }^{* *}$ $P<0.01$ vs. $A \beta$-treated group.

Effect of Sanguisorba minor and Ferulago angulata on AChE activity

The CGNs were treated with different concentrations of S.minor extract $(5-100 \mu \mathrm{g} / \mathrm{mL})$ and $F$. angulata extract $(10-200 \mu \mathrm{g} / \mathrm{mL})$, and AChE activity was measured after 24 hours. Results indicated that S. minor extract dose dependently reduced the enzyme activity (Figure $4 \mathrm{~A}$ ) but F. angulata extract about $50 \%$ reduced enzyme activity even in high concentration (Figure $4 B$ ). Effect of $A \beta$ and $A \beta+$ extract on $A C h E$ activity was also investigated. $A \beta$ treatment significantly increased the AChE activity in CGNs. Co-treatment of $A \beta$ with both extracts significantly decreased the $\mathrm{AChE}$ activity as compared with $\mathrm{A} \beta$ group (Figure 4C).

\section{$\mathrm{LD}_{50}$ test}

According to OECD protocol, limit test was performed for estimation of LD50. Because all the animals which treated $2000 \mathrm{mg} / \mathrm{kg}$ extract survived, LD50 was considered to be more than $2000 \mathrm{mg} / \mathrm{kg}$ for both extracts. Treated animals were monitored for 14 days. There was no illness in apparent health during the observed period and a significant difference in body weight changes was not observed between extract treated and control groups.

\section{Discussion}

In the present study neuroprotective effects of S. minor and
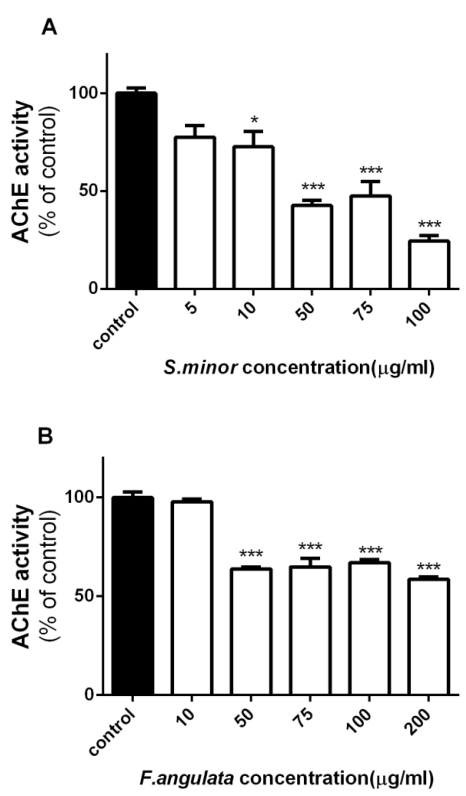

C

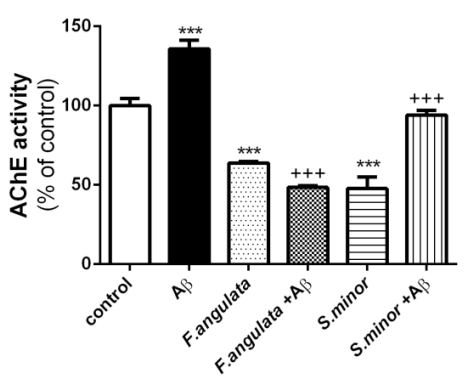

Figure 4. Acetylcholinestrase (AChE) activity in cerebellar granule neurons. (A) AChE activity after incubation with different concentration of Sanguisorba minor extract. (B) AChE activity after incubation with different concentrations of Ferulago angulata extract. (C) AChE activity after treatment with $A \beta$ alone or in combination with extracts. ${ }^{*} P<0.05$ and ${ }^{* * *}$ $P<0.001$ vs. control, ${ }^{++} P<0.01$ vs. A $\beta$-treated group.

F. angulata extracts against $\mathrm{A} \beta$-induced toxicity in cultured CGNs were investigated. The CGNs grew and developed after birth and produced a homogeneous population of neurons in culture, Therefore, primary culture of CGNs was used as a suitable model for studying cellular and molecular mechanisms of neural cell apoptosis, survival, neurodegeneration and neuroprotection (31). Also CGNs culture was used for studying the neurotoxicity of $A \beta$ peptide $(26,32)$.

Results of the present study indicated that S. minor and $F$. angulata extracts significantly ameliorated the $A \beta$ induced cytotoxicity in cultured CGNs. Also, A $\beta$-induced increase in ROS production and decrease in GPx activity, as an antioxidant enzyme, were significantly restored by pretreatment with S. minor and F. angulata extracts which indicates that $A \beta$-induced oxidative stress was significantly attenuated by these extracts. Several studies have reported that $\mathrm{A} \beta$ peptide in aggregated form produced neurotoxicity and has a pivotal role in neural cell loss and progression of $\mathrm{AD}$ disease and also oxidative stress plays crucial roles in 
A $\beta$-induced toxicity $(8,33,34)$. Medicinal plants which are rich in polyphenol compounds have strong antioxidant activity and protects neurons from oxidative insults (35). Several medicinal plants such as Gingko biloba, Crocus sativus, Curcuma longa and Melissa officinalis have been shown to prevent oxidative stress in cultured neurons and brain tissue that is associated with $\mathrm{AD}$ (18). Our results indicated that $S$. minor and $F$. angulata extracts had $11.06 \pm 0.55$ and $2.11 \pm 0.08 \mathrm{mg} / \mathrm{g}$ dried extract total phenol contents, respectively. This finding indicated that S. minor has a high level of phenolic compounds which is in agreement with a previous study (20). Sanguisorba species have potent antioxidant activities and some studies have reported the neuroprotective effects for plants of this species. Sanguisorbae officinalis root extract has elicited neuroprotective activity and protect cortical neuron culture from $\mathrm{H} 2 \mathrm{O} 2$-induced oxidative stress (36). In addition, $S$. minor could significantly scavenge the peroxyl $(\mathrm{H} 2 \mathrm{O} 2)$ and hydroxyl $(\mathrm{OH})$ radicals. The genus Sanguisorba contains several biologically active compounds and to date, more than 120 compounds have been isolated and identified from them. Among these compounds, phenols and flavonoids are responsible for the antioxidant properties of these plants. Gallic acid, quercetin and ellagic acid are polyphenolic compounds isolated from S. minor extract (20). These polyphenolic compounds have neuroprotective activity and protect cultured neurons and brain tissue against oxidative damages caused by $A \beta$ peptide (37-39). Then, it is suggested that neuroprotective effect of $S$. minor against $\mathrm{A} \beta$-induced toxicity, at least partly, is due to the presence of these phenolic compounds.

Ferulago angulata is a plant belongs to Apiaceae family. In traditional medicine, it is used as a sedative agent (23). Neuroprotective activity has been reported for F. angulata extract by several studies. Hydro-alcoholic extract of $F$. angulata improves locomotor activity, anxiety, memory and pain in animal models of ischemia $(24,25)$. Also, F. angulata extract attenuates oxidative stress in brain tissue in a rat model of Parkinson's disease (40). Essential oil of F. angulata has cognition-enhancing effect and improves scopolamine-induced memory impairment and oxidative stress (41). In the present study, F. angulata extract significantly ameliorated $\mathrm{A} \beta$-induced neuronal cell death and attenuated $\mathrm{A} \beta$-induced ROS production and oxidative stress. F. angulata extract contains phenolic and flavonoid compounds and has potent antioxidant activity. The neuroprotective activity of the extract has been attributed to these compounds (25). The phenolic and flavonoid compounds have antioxidant activities directly by radical scavenging of the free radicals or indirectly through upregulation of cellular antioxidant defense pathways which provides neuroprotection against oxidative damage. In addition to antioxidant activity, polyphenols protect neural cells against oxidative insults through activation of cell survival signaling pathways such as MAP kinase and PI3K/Act (42).

AChE enzyme has a crucial role in $A \beta$ toxicity and progression of $\mathrm{AD}$. Increased activity of $\mathrm{AChE}$ around the amyloid plaques has been observed in the $\mathrm{AD}$ brain and also AChE protein has been found to be abundant in amyloid plaques and co-localized with $A \beta$ peptide (43). It is reported that $\mathrm{AChE}$ protein stimulates $\mathrm{A} \beta$ peptide aggregation and produces $\mathrm{AChE}-\mathrm{A} \beta$ complex which is more neurotoxic than $\mathrm{A} \beta$ alone (44). On the other hand, the in vitro studies have indicated that exposure of cultured neurons to $A \beta$ peptide increases AChE activity (45). Similar findings have been observed in animal studies and injection of $A \beta$ peptide in the brain increases brain AChE activity which is associated with learning and memory deficit(17). AChE inhibitors such as donepezil, rivastagmine and galantamine are commonly used for the treatment of AD. Inhibition of AChE activity increases the brain acetylcholine level which is resulted in improved memory function. Besides of this mechanism, AChE inhibitors attenuate the $A \beta$-induced toxicity and oxidative stress (11). Then, inhibition of AChE is an approach to reduce the $A \beta$-induced neurotoxicity. In addition, inhibition of $\mathrm{A} \beta$-induced $\mathrm{AChE}$ activity, boosts brain cholinergic function and improves $\mathrm{AD}$ symptoms. In the present study, S. minor extract dose-dependently inhibited AChE activity in cultured CGNs. At dose of $100 \mu \mathrm{g} / \mathrm{mL}$ significant inhibition of AChE activity about (80\%) was observed. This finding is accordance with a previous study which reported that $S$. minor extract inhibits pure AChE from red blood cells (22). Also our results indicated that $\mathrm{A} \beta$ exposure for 24 hours significantly increased AChE activity in cultured CGNs. S. minor extract significantly inhibited the AChE activity which was elevated by $\mathrm{A} \beta$ exposure. According to these findings, it is concluded that AChE inhibitory effect of $S$. minor extract was contributing to its protective effect against $A \beta$ neurotoxicity.

Ferulago angulata extract inhibited AChE activity too, but its effect was less than $S$. minor extract and maximum effect (about 50\% inhibition) was observed at $200 \mu \mathrm{g} /$ $\mathrm{mL}$ concentration. This finding is in accordance with a previous study which reported weak AChE inhibitory effect for F. angulata extract (46). Despite the low AChE inhibitory effect, $F$. angulata extract significantly reduced the increased AChE activity induced by $A \beta$ treatment. The exact mechanisms by which $A \beta$ increases AChE activity and expression in the cell culture and amyloid plaques in the brain are not known. There is some evidence that $\mathrm{A} \beta$-induced oxidative stress and disruption of calcium homeostasis are involved (45). The oxidative stress increases AChE activity and this increase is ameliorated with antioxidants which do not have AChE inhibitory effect $(26,47)$. According to these reports and our findings, it is concluded that $F$. angulata extract restores the increases in the $\mathrm{A} \beta$-induced $\mathrm{AChE}$ activity by reduction of $\mathrm{A} \beta$-induced oxidative stress. Although other mechanisms may be involved which needs further investigation. 
The results of $\mathrm{LD}_{50}$ experiment of these extracts showed that LD50s of both extracts were higher than $2000 \mathrm{mg} / \mathrm{kg}$. According to the OECD protocol, they are considered to be non-toxic compounds and can be safely used.

\section{Conclusion}

Our study indicated that $S$. minor and F. angulata extracts could improve $A \beta$-induced cytotoxicity and oxidative stress. It is suggested that protective effects of both extracts are due to their antioxidant activities. Also, for S. minor extract the AChE inhibitory effect of the extract may be involved. According to these findings, further studies are suggested to evaluate the effects of $S$. minor and F. angulata extracts as therapeutic agents in AD.

\section{Authors' contributions}

MS, supervisor, designed and managed the project, analyzed and interpreted the data, and revised the final version of the manuscript. $\mathrm{HH}$, advisor, was involved in plant collection and extract preparation and determination of extract total phenols. SA performed cell culture and biochemical experiments and prepared the initial draft of the manuscript. NA performed $\mathrm{LD}_{50}$ test. All read and confirmed the final version of the manuscript for publication.

\section{Conflict of interests}

The authors declare no conflict of interest.

\section{Ethical considerations}

All animal experimental procedures were approved by the Medical Ethics Committee of Tarbiat Modares University (Ethical code: IR.TMU.IEC.1394.157).

\section{Funding/Support}

This work was financially supported by Tarbiat Modares University as a MSc thesis.

\section{References}

1. Small DH, Cappai R. Alois Alzheimer and Alzheimer's disease: a centennial perspective. J Neurochem. 2006;99(3):708-10. doi: 10.1111/j.1471-4159.2006.04212.x.

2. De-Paula VJ, Radanovic M, Diniz BS, Forlenza OV. Alzheimer's disease. Subcell Biochem. 2012;65:329-52. doi: 10.1007/978-94-007-5416-4_14.

3. Dos Santos Picanco LC, Ozela PF, de Fatima de Brito Brito M, Pinheiro AA, Padilha EC, Braga FS, et al. Alzheimer's disease: a review from the pathophysiology to diagnosis, new perspectives for pharmacological treatment. Curr Med Chem. 2018;25(26):3141-59. doi: 10.2174/09298673236661 61213101126.

4. Francis PT, Palmer AM, Snape M, Wilcock GK. The cholinergic hypothesis of Alzheimer's disease: a review of progress. J Neurol Neurosurg Psychiatry. 1999;66(2):13747.

5. Prasansuklab A, Tencomnao T. Amyloidosis in Alzheimer's disease: the toxicity of amyloid beta (A beta), mechanisms of its accumulation and implications of medicinal plants for therapy. Evid Based Complement Alternat Med. 2013;2013:413808. doi: 10.1155/2013/413808.

6. Barage SH, Sonawane KD. Amyloid cascade hypothesis: Pathogenesis and therapeutic strategies in Alzheimer's disease. Neuropeptides. 2015;52:1-18. doi: 10.1016/j. npep.2015.06.008.

7. Pike CJ, Burdick D, Walencewicz AJ, Glabe CG, Cotman CW. Neurodegeneration induced by beta-amyloid peptides in vitro: the role of peptide assembly state. J Neurosci. 1993;13(4):1676-87.

8. Sun X, Chen WD, Wang YD. beta-Amyloid: the key peptide in the pathogenesis of Alzheimer's disease. Front Pharmacol. 2015;6:221. doi: 10.3389/fphar.2015.00221.

9. Cavallucci V, D'Amelio M, Cecconi F. Abeta toxicity in Alzheimer's disease. Mol Neurobiol. 2012;45(2):366-78. doi: 10.1007/s12035-012-8251-3.

10. Cho JE, Kim JR. Recent approaches targeting beta-amyloid for therapeutic intervention of Alzheimer's disease. Recent Pat CNS Drug Discov. 2011;6(3):222-33.

11. Kulshreshtha A, Piplani P. Current pharmacotherapy and putative disease-modifying therapy for Alzheimer's disease. Neurol Sci. 2016;37(9):1403-35. doi: 10.1007/s10072-0162625-7.

12. Batool A, Kamal MA, Rizvi SMD, Rashid S. Topical discoveries on multi-target approach to manage Alzheimer's Disease. Curr Drug Metab. 2018;19(8):704-13. doi: 10.2174 /1389200219666180305152553.

13. Orhan IE, Senol FS. Designing multi-targeted therapeutics for the treatment of Alzheimer's disease. Curr Top Med Chem. 2016;16(17):1889-96.

14. Sahoo AK, Dandapat J, Dash UC, Kanhar S. Features and outcomes of drugs for combination therapy as multi-targets strategy to combat Alzheimer's disease. J Ethnopharmacol. 2018;215:42-73. doi: 10.1016/j.jep.2017.12.015.

15. Ambure P, Bhat J, Puzyn T, Roy K. Identifying natural compounds as multi-target-directed ligands against Alzheimer's disease: an in silico approach. J Biomol Struct Dyn. 2019;37(5):1282-306. doi: 10.1080/07391102.2018.1456975.

16. Howes MJ, Houghton PJ. Ethnobotanical treatment strategies against Alzheimer's disease. Curr Alzheimer Res. 2012;9(1):67-85.

17. Soodi M, Saeidnia S, Sharifzadeh M, Hajimehdipoor H, Dashti A, Sepand MR, et al. Satureja bachtiarica ameliorate beta-amyloid induced memory impairment, oxidative stress and cholinergic deficit in animal model of Alzheimer's disease. Metab Brain Dis. 2016;31(2):395-404. doi: 10.1007/ s11011-015-9773-y.

18. Akram M, Nawaz A. Effects of medicinal plants on Alzheimer's disease and memory deficits. Neural Regen Res. 2017;12(4):660-70. doi: 10.4103/1673-5374.205108.

19. Karkanis A, Vellios E, Thomaidis T, Bilalis D, Efthimiadou A, Travlos I. Phytochemistry and biological properties of burnet weed (Sanguisorba spp.): A review. Not Sci Biol. 2014;6(4):395-8. doi: 10.15835/nsb649471.

20. Zhao Z, He X, Zhang Q, Wei X, Huang L, Fang JC, et al. Traditional uses, chemical constituents and biological activities of plants from the genus Sanguisorba L. Am J Chin Med. 2017;45(2):199-224. doi: 10.1142/ 
s0192415x17500136.

21. Anand P, Singh B. Flavonoids as lead compounds modulating the enzyme targets in Alzheimer's disease. Med Chem Res. 2013;22(7):3061-75. doi: 10.1007/s00044-0120353-y.

22. Esmaeili S, Ara L, Hajimehdipoor H, Kolivand $\mathrm{H}$, Mohammadi Motamed S. Acetylcholinesterase inhibitory effects of some plants from Rosaceae. Res J Pharmacogn. 2015;2(4):33-7.

23. Lorigooini Z, Koravand $M$, Haddadi H, RafieianKopaei M, Shirmardi HA, Hosseini Z. A review of botany, phytochemical and pharmacological properties of Ferulago angulata. Toxin Rev. 2019;38(1):13-20. doi: 10.1080/15569543.2017.1399277.

24. Alami-Rostami S, Rafieirad M. The effect of hydroalcoholic Ferulago angulata extract on locomotor activity and anxiety caused by hypoperfusion ischemia in adult male rats. J Herbmed Pharmacol. 2018;7(1):51-5. doi: 10.15171/jhp.2018.09.

25. Mirzapour S, Rafieirad M, Rouhi L. Hydroalcoholic extract of Ferulago angulata improves memory and pain in brain hypoperfusion ischemia in rats. Jundishapur J Nat Pharm Prod. 2015;10(1):e17451.

26. Soodi M, Dashti A, Hajimehdipoor H, Akbari S, Ataei N. Melissa officinalis acidic fraction protects cultured cerebellar granule neurons against beta amyloid-induced apoptosis and oxidative stress. Cell J. 2017;18(4):556-64.

27. Mosmann T. Rapid colorimetric assay for cellular growth and survival: application to proliferation and cytotoxicity assays. J Immunol Methods. 1983;65(1-2):55-63.

28. Wang H, Joseph JA. Quantifying cellular oxidative stress by dichlorofluorescein assay using microplate reader. Free Radic Biol Med. 1999;27(5-6):612-6.

29. Ellman GL, Courtney KD, Andres V Jr, Feather-Stone RM. A new and rapid colorimetric determination of acetylcholinesterase activity. Biochem Pharmacol. 1961;7:88-95.

30. OECD. Test No. 425: Acute Oral Toxicity: Up-and-Down Procedure. OECD Guidelines for the Testing of Chemicals, Section 4. Paris: OECD Publishing; 2008.

31. Contestabile A. Cerebellar granule cells as a model to study mechanisms of neuronal apoptosis or survival in vivo and in vitro. Cerebellum. 2002;1(1):41-55. doi: $10.1080 / 147342202753203087$.

32. Wei H, Leeds PR, Qian Y, Wei W, Chen R, Chuang D. beta-amyloid peptide-induced death of PC 12 cells and cerebellar granule cell neurons is inhibited by long-term lithium treatment. Eur J Pharmacol. 2000;392(3):117-23.

33. Carrillo-Mora P, Luna R, Colin-Barenque L. Amyloid beta: multiple mechanisms of toxicity and only some protective effects? Oxid Med Cell Longev. 2014;2014:795375. doi: 10.1155/2014/795375.

34. Ferreira ME, de Vasconcelos AS, da Costa Vilhena T, da Silva TL, da Silva Barbosa A, Gomes AR, et al. Oxidative stress in Alzheimer's disease: should we keep trying antioxidant therapies? Cell Mol Neurobiol. 2015;35(5):595614. doi: 10.1007/s10571-015-0157-y.
35. Darvesh AS, Carroll RT, Bishayee A, Geldenhuys WJ, Van der Schyf CJ. Oxidative stress and Alzheimer's disease: dietary polyphenols as potential therapeutic agents. Expert Rev Neurother. 2010;10(5):729-45. doi: 10.1586/ern.10.42.

36. Nguyen TT, Cho SO, Ban JY, Kim JY, Ju HS, Koh SB, et al. Neuroprotective effect of Sanguisorbae radix against oxidative stress-induced brain damage: in vitro and in vivo. Biol Pharm Bull. 2008;31(11):2028-35.

37. Mansouri SMT, Naghizadeh B, Ghorbanzadeh B, Farbood Y, Sarkaki A, Bavarsad K. Gallic acid prevents memory deficits and oxidative stress induced by intracerebroventricular injection of streptozotocin in rats. Pharmacol Biochem Behav. 2013;111:90-6. doi: 10.1016/j.pbb.2013.09.002.

38. Jha AB, Panchal SS, Shah A. Ellagic acid: Insights into its neuroprotective and cognitive enhancement effects in sporadic Alzheimer's disease. Pharmacol Biochem Behav. 2018;175:33-46. doi: 10.1016/j.pbb.2018.08.007.

39. Ansari MA, Abdul HM, Joshi G, Opii WO, Butterfield DA. Protective effect of quercetin in primary neurons against Abeta (1-42): relevance to Alzheimer's disease. J Nutr Biochem. 2009;20(4):269-75. doi: 10.1016/j. jnutbio.2008.03.002.

40. Sharifi F, Rafieirad M, Sazegar H. Effects of Ferulago angulata extract against oxidative stress induced by 6-hydroxydopamine in rats. Journal of Medicinal Plants. 2015;1(53):34-44.

41. Hritcu L, Bagci E, Aydin E, Mihasan M. Antiamnesic and Antioxidants Effects of Ferulago angulata essential oil against scopolamine-induced memory impairment in laboratory rats. Neurochem Res. 2015;40(9):1799-809. doi: 10.1007/s11064-015-1662-6.

42. Ebrahimi A, Schluesener H. Natural polyphenols against neurodegenerative disorders: potentials and pitfalls. Ageing Res Rev. 2012;11(2):329-45. doi: 10.1016/j.arr.2012.01.006.

43. Moran MA, Mufson EJ, Gomez-Ramos P. Colocalization of cholinesterases with beta amyloid protein in aged and Alzheimer's brains. Acta Neuropathol. 1993;85(4):362-9.

44. Alvarez A, Alarcon R, Opazo C, Campos EO, Munoz $\mathrm{FJ}$, Calderon $\mathrm{FH}$, et al. Stable complexes involving acetylcholinesterase and amyloid-beta peptide change the biochemical properties of the enzyme and increase the neurotoxicity of Alzheimer's fibrils. J Neurosci. 1998;18(9):3213-23.

45. Sberna G, Saez-Valero J, Beyreuther K, Masters CL, Small $\mathrm{DH}$. The amyloid beta-protein of Alzheimer's disease increases acetylcholinesterase expression by increasing intracellular calcium in embryonal carcinoma P19 cells. J Neurochem. 1997;69(3):1177-84.

46. Hajimehdipoor H, Shekarchi M, Aghighi A, HamzelooMoghadam M. Evaluating the acetylcholinesterase inhibitory activity of Ferulago angulata and Ferulago subvelutina. Res J Pharmacogn. 2014;1(2):39-43.

47. Hartl R, Gleinich A, Zimmermann M. Dramatic increase in readthrough acetylcholinesterase in a cellular model of oxidative stress. J Neurochem. 2011;116(6):1088-96. doi: 10.1111/j.1471-4159.2010.07164.x. 